\title{
Vulnerabilidade Externa Brasileira nos anos 1980: uma Análise a partir da Posição Internacional de Investimentos e do Fluxo de Rendas
}

\section{Brazilian Foreign Vulnerability in the 1980s: an Analysis of the International Investment Position and Income Flows}

Julio Manuel Pires*

Paulo Van Noije**

Bruno de Conti***

\begin{abstract}
Resumo: O objetivo do trabalho é apresentar a vulnerabilidade externa brasileira na década de 1980, em sua esfera financeira, decorrente dos estoques externos. Defendese a hipótese de que, historicamente, um dos elos mais importantes da interação entre os fluxos e os estoques externos brasileiros está na sua circularidade. Para as análises em tela, realiza-se uma estimativa da Posição Internacional de Investimentos para os anos 1980 que é inédita - já que esses dados não são disponibilizados por nenhuma fonte oficial -, constituindo-se como uma das contribuições do artigo. Ademais, apresenta-se uma estimativa - também inédita - da rentabilidade desses estoques externos, além de alguns indicadores de endividamento externo. A partir desses dados, o artigo analisa o período marcado pela crise da dívida externa no Brasil, concluindo que os saldos positivos gerados pelas exportações serviram apenas para amenizar a circularidade entre a Posição Internacional de Investimentos e as rendas enviadas, atenuando o aumento do passivo externo líquido ao longo do período analisado e gerando, em contrapartida, um baixo dinamismo econômico e o aumento das pressões inflacionárias.
\end{abstract}

Palavras-chave: Vulnerabilidade externa. Posição internacional de investimentos. Fluxo de rendas. Crise da dívida. Economia brasileira.

\begin{abstract}
The objective of this paper is to present the Brazilian external vulnerability in the 1980s, in the financial sphere, resulting from foreign stocks. The paper supports the hypothesis that, historically, one of the most important links of the interaction between flows and external stocks in Brazil is in its circularity. In order to enable these analyses, the paper makes an estimation of the Brazilian International Investment Position in 1980 that is original and novel - since there are no official data for it -, what is certainly one of the contributions of this article. Moreover, it presents an estimation - also original - for the yield of these foreign

* Doutor em Economia pela Universidade de São Paulo. Professor titular do Departamento de Economia e do Programa de Estudos Pós-Graduados em Economia Política da Pontifícia Universidade Católica de São Paulo (PUCSP) e da Faculdade de Economia, Administração e Contabilidade de Ribeirão Preto da Universidade de São Paulo. E-mail: jmpires@usp.br

** Doutor em Economia pela Universidade Estadual de Campinas (Unicamp). Professor da Faculdade de Ciências Aplicadas da Unicamp. Pesquisador do Centro de Estudos de Conjuntura e Política Econômica (Cecon) da Unicamp. E-mail: paulovannoije@yahoo.com.br

$* *$ Doutor em Economia pela Unicamp e pela Universidade Paris 13. Professor do Instituto Economia da Unicamp. Pesquisador do Centro de Estudos de Conjuntura e Política Econômica (Cecon) da Unicamp. E-mail: bmdeconti@gmail.com
\end{abstract}


stocks and some external debt indicators. Using these data, the paper analyzes the period marked by the Brazilian debt crisis in the 1980s, concluding that the surpluses generated by exports only served to soften the circularity between the International Investment Position and sent rents, reducing the increase in net foreign liabilities over the period, but generating a low economic dynamism and increasing inflationary pressures.

Keywords: External vulnerability. International Investment Position. Income flows. Debt crisis. Brazilian economy.

JEL Classification: N16, G00, E01.

\section{Introdução}

O presente trabalho tem como objetivo avaliar a relação entre os fluxos e estoques externos da economia brasileira na década de 1980, e como essa interação afetou a vulnerabilidade externa do país durante esses anos.

Vale ressaltar que os dados dos estoques externos não estão disponibilizados para a economia brasileira na década em questão, portanto, a estimativa realizada é uma das principais contribuições dessa pesquisa. Adicionalmente, apresenta-se uma estimativa - também inédita - da rentabilidade desses estoques externos. Além disso, uma das grandes vantagens de estudar o passado é tentar entender o presente. Nesse sentido, o referencial teórico utilizado pode ser útil para analisar outras economias e períodos.

No caso brasileiro, pode-se considerar que as rendas líquidas enviadas ao exterior exercem uma pressão por geração de divisas desde longa data. Embora não haja dados disponíveis sobre o balanço de pagamentos brasileiro antes de 1871, sabe-se que o reconhecimento da independência por parte da Inglaterra e de Portugal dependeu da assunção, pelo Brasil, de parte da dívida portuguesa com os britânicos. Portanto, desde os primórdios do país como nação independente, já se observam encargos associados ao pagamento de juros. Os dados para o período 1871-1900 revelam valores líquidos sistematicamente negativos para os itens relacionados a juros e remessas de lucros, os quais se incrementaram de forma substancial na primeira década republicana. Assim, em muitos anos do período, os recorrentes superávits comerciais não foram suficientes para cobrir os resultados negativos na conta de rendas, resultando em seguidos déficits nas transações correntes. Desta maneira, ao menos desde as últimas décadas do século XIX, o Brasil já tinha uma permanente necessidade de geração de divisas para poder honrar o pagamento dessas rendas, tendo que aumentar seu passivo externo, já que dependia da obtenção de novos empréstimos estrangeiros. Segundo Abreu (2002), entre o início da República e o final da Segunda Guerra Mundial, o Brasil realizou três operações de renegociação dos termos da dívida externa, quando foram acertados empréstimos de consolidação (Funding Loans de 1898, 1914 e 1931). 
Na década de 1930, o serviço da dívida externa foi retomado em 1934, através do chamado esquema Aranha, com vigência prevista para quatro anos. Antes que se completasse esse prazo, o golpe de 1937 serviu de pretexto para o único episódio de default completo por parte do governo central brasileiro antes de 1987. Novo acordo temporário passou a vigorar em 1940, batizado de esquema Souza Costa, e, finalmente, em 1943, um acordo permanente equacionou o pagamento do serviço da dívida externa contraída até 1931. (ABREU, 2002, p. 518).

Dessa forma, um dos elos mais importantes dessa interação entre fluxos e estoques externos brasileiros está na sua circularidade: a Posição Internacional de Investimentos (PII) negativa causa uma saída de rendas e este fluxo, não tendo uma contrapartida equivalente nos saldos positivos da balança comercial e de serviços, torna o país dependente do financiamento externo, caracterizando, em última instância, uma vulnerabilidade externa. Um dos objetivos deste trabalho é demonstrar como essa circularidade evoluiu na década de 1980, um dos períodos mais críticos da economia brasileira no tocante aos problemas do balanço de pagamentos.

A situação de escassez de liquidez em âmbito internacional afetou duramente a economia brasileira na década de 1980, manifestando a vulnerabilidade externa decorrente da PII e do fluxo de rendas. Nesse período, o país utilizou todos os instrumentos disponíveis em prol do objetivo de transferir recursos reais ao exterior para servir aos encargos dos estoques externos. A política de ajustamento realizada gerou saldos positivos na balança comercial - com uma forte diminuição da absorção interna -, porém contribuiu para a deterioração das contas públicas, o baixo dinamismo econômico e o aumento das pressões inflacionárias.

A segunda seção aborda a conceituação da PII e dos determinantes de sua evolução; a terceira explica a vulnerabilidade externa decorrente da PII e do fluxo de rendas; a quarta trata do contexto internacional e das políticas econômicas internas dos anos 1980; a quinta apresenta uma estimativa da PII para a década em questão; a sexta examina as rendas líquidas enviadas no período; na sétima, realiza-se uma estimativa de rentabilidade dos estoques externos; e na oitava, apresenta-se como a circularidade entre a PII e as rendas líquidas enviadas evoluiu na década de 1980. Algumas considerações finais encerram o artigo.

\section{Posição Internacional de Investimentos: Estrutura, Conceituação e Deter- minantes de sua Evolução}

A Posição Internacional de Investimentos (PII) é a diferença entre os ativos e os passivos externos brutos de um país. O cálculo e a apresentação, no Quadro 1, da PII seguem a metodologia da quinta edição do Manual do Balanço de 
Pagamentos do Fundo Monetário Internacional (SIMONSEN; CYSNE, 2007). A categorização dos estoques de ativos e passivos na PII corresponde aos componentes da conta financeira do Balanço de Pagamentos (BP): ${ }^{1}$ investimento direto, investimento em portfólio, derivativos e outros investimentos.

Quadro 1 - Estrutura da posição internacional de investimento (PII). PII = Ativo externo bruto (A) - Passivo externo bruto (B)

\begin{tabular}{|l|l|}
\hline (A) Ativo Externo Bruto & (B) Passivo Externo Bruto \\
\hline Investimento direto no exterior & Investimento direto estrangeiro \\
Investimento em carteira & Investimento em carteira \\
Derivativos & Derivativos \\
Outros investimentos & Outros investimentos \\
Ativos de reservas & \\
\hline
\end{tabular}

Fonte: Elaboração própria com base em Banco Central do Brasil (2017)

Tradicionalmente, não se utiliza o termo PII nas discussões sobre os estoques externos, sendo primordialmente empregado o termo Passivo Externo Líquido (PEL). Existem duas maneiras de se calcular o PEL (CYSNE, 2008):

a) PEL1: O Passivo Externo Líquido 1 é igual ao déficit acumulado na conta corrente do balanço de pagamentos; no caso brasileiro, esse valor é calculado pelos dados acumulados a partir de 1947;

b) PEL2: O Passivo Externo Líquido 2 é calculado como o estoque do passivo externo menos o estoque do ativo externo, ou seja, o oposto da PII, de forma que o PEL2 = - PII.

Para a explicação dos conceitos de passivos externos líquidos (PEL1 e PEL2) e da PII, utilizam-se as seguintes igualdades:

$$
\begin{aligned}
& S T C_{t}=-S C F_{t}+\triangle R E S \\
& \triangle P E L 1_{t}=-S T C_{t} \\
& -\sum_{i=1} S T C_{i}=P E L 1=D C C A \\
& P E L 2=P E L 1+V \\
& A_{e x t}-P_{\text {ext }}=P I I=-P E L 2
\end{aligned}
$$

1 A única diferença é a inclusão das reservas internacionais no item "Ativos de Reservas".

2 Ano a partir do qual o Banco Central do Brasil (BCB) disponibiliza os dados do BP brasileiro. Supõe-se, por simplificação, um passivo externo líquido igual a zero no início de 1947 (SIMONSEN; CYSNE, 2007). 
em que STC é o saldo em transações correntes, SCF é o saldo na conta financeira, RES são as reservas internacionais, PEL1 é o passivo externo líquido1, PEL2 é o passivo externo líquido2, DCCA é o déficit acumulado na conta corrente do balanço de pagamentos, $\mathrm{A}_{\text {ext }}$ é o estoque de ativos externos, $\mathrm{P}_{\text {ext }}$ é o estoque de passivos externos, PII é a Posição Internacional de Investimento e $V$ são as valorizações ou desvalorizações de ativos e passivos externos, monetizações ou desmonetizações de ouro e alocações ou cancelamentos de DES. ${ }^{3}$

Identifica-se por (1) que o saldo em transações correntes é igual ao oposto do saldo da conta financeira mais a variação das reservas internacionais, ou seja, um déficit em transações correntes no ano t é financiado pela entrada de capitais estrangeiros no ano t e/ou pela queda das reservas internacionais, gerando, conforme se observa em (2), um aumento do passivo externo líquido 1 (PEL1) no ano t.

Já por (3), o PEL1 pode ser entendido como o déficit acumulado na conta corrente do balanço de pagamentos, ou seja, o somatório (do oposto) dos saldos em conta corrente gera o Passivo Externo Líquido 1, retratando a parcela do PEL de uma economia que se explica unicamente em função do histórico de transações entre residentes e não residentes (CYSNE, 2008).

Entretanto, conforme (4), o PEL1 e o PEL2 só serão iguais caso não ocorram as variações "V": valorizações ou desvalorizações de ativos e passivos; monetizações ou desmonetizações de ouro; e alocações ou cancelamentos de DES.

Dessa maneira, pode-se dizer que a variável PEL1 é mais fácil de ser calculada do que PEL2, mas a segunda retrata o PEL de forma mais fidedigna. Assim, sempre que possível, será utilizado o método PEL2 na estimativa da PII; contudo, no cálculo de alguns estoques externos, será utilizado o método PEL1.

Para analisar como ocorrem as variações dos saldos das posições patrimoniais, será utilizada a seguinte identidade, que relaciona as diferentes contas da PII em dois pontos distintos no tempo (ARAUJO, 2008):

$$
A_{N}-A_{0}=V A A+O M V+G D N
$$

em que $\mathrm{A}_{0}$ e $\mathrm{A}_{\mathrm{N}}$ são os valores do ativo ou passivo na estatística de PII em um momento inicial $(i=0)$ e em outro final $\left(i={ }_{N}\right)$, VAA é o valor associado às quantidades de ativo adquirido ou cedido nas transações registrado no BP, OMV é o valor associado a outras mudanças do volume do ativo, e GDN é o valor do ganho associado à detenção nominal do ativo.

Assim, pode-se considerar (cf. ARAUJO, 2008) a variação de uma conta da PII num intervalo " $\mathrm{n}$ " como sendo igual a (6), ou seja, por " $\mathrm{A}_{\mathrm{N}}-\mathrm{A}_{0}$ ", decorrente da possibilidade de alterações em três variáveis, que são:

3 Direito Especial de Saque. 
a) VAA: "[...] representam fluxos financeiros explicitados nas transações da conta financeira do BP [...]";

b) OMV: são decorrentes de variações no volume de ativos e não são captados pelo BP, entre as quais se pode citar: alocação e cancelamento dos direitos especiais de saque do FMI; cancelamento de débitos; monetização e desmonetização de ouro; lançamentos de contrapartida; reclassificações; e medidas de erro;

c) GDN: são os ganhos com a detenção de ativos financeiros e não financeiros decorrentes de variações nos preços, entre eles, a variação da taxa de câmbio.

Cysne (2008) argumenta que o GDN é a variação ("V") mais relevante. Considerando que as OMV apresentam valores pouco expressivos (ARAUJO, 2006, p. 7), atribui-se valor zero para essa variável no restante da pesquisa, e se concentrará na discussão do GDN e das VAA.

\section{A Vulnerabilidade Externa decorrente da Circularidade entre a Posição Internacional de Investimentos e o Fluxo de Rendas}

A vulnerabilidade externa de um determinado país se manifesta em distintas dimensões, devendo ser destacadas as esferas comercial, produtivo-tecnológica e monetário-financeira. No entanto, a despeito do amplo tratamento dado ao tema da vulnerabilidade, as análises usualmente restringem-se a apenas uma daquelas esferas, qual seja, a do comércio exterior. Conforme aponta Gonçalves (1998), esse enfoque restritivo resulta em um conjunto de modelos de crise do balanço de pagamentos que considera as rendas líquidas enviadas ao exterior como nulas, uma simplificação que pode comprometer bastante as análises. Esse artigo pretende, portanto, colaborar com o preenchimento dessa lacuna por meio da atenta observação da esfera financeira da vulnerabilidade e, notadamente, da interação entre os estoques externos e as rendas enviadas/recebidas do exterior.

A economia brasileira, em termos históricos, é estruturalmente deficitária em rendas. Esses recursos que devem ser enviados ao exterior determinam uma permanente necessidade de geração de divisas, geralmente não satisfeita pelos superávits da balança comercial e de serviços. ${ }^{4}$ Com isso, o país fica dependente do financiamento estrangeiro para fechar suas contas externas, configurando uma das principais causas da vulnerabilidade externa do país.

4 Relativamente à balança comercial, cujos dados estão disponibilizados desde 1821, é importante destacar que, após as quatro primeiras décadas seguintes a 1822, quando o país apresentou déficits na maioria dos anos, a ocorrência destes tornou-se rara posteriormente. Nos mais de 150 anos desde então, em apenas dezoito as importações excederam as exportações, cabendo chamar a atenção para o fato de que oito destes anos ocorreram entre 1971 e 1980 e seis entre 1995 e 2000. (BANCO CENTRAL DO BRASIL, 2017; IBGE, 1990, p. 568-569; IPEADATA, 2017). 
A interação entre fluxos e estoques determina, portanto, uma "circularidade" - ou uma dinâmica de retroalimentação - cuja compreensão é essencial para o tema em tela, já que uma Posição Internacional de Investimentos negativa causa uma saída de rendas e este fluxo contribui com o aumento do passivo externo.

Destarte, fica nítido que um importante determinante da vulnerabilidade externa são os desequilíbrios entre os estoques de passivo e de ativo externo, que geram fluxos de rendas que muitas vezes condicionam os resultados das outras contas do Balanço de Pagamentos, especialmente no caso dos países deficitários em rendas. Estes geralmente são impelidos a atrelar suas estratégias de inserção externa à necessidade de geração de divisas para fazer frente aos desequilíbrios entre seus passivos e ativos externos.

Assim, para analisar de que forma a PII e as rendas líquidas enviadas afetam a vulnerabilidade externa, deve-se levar em conta três aspectos referentes aos estoques externos: i) suas magnitudes; ii) suas rentabilidades; e iii) suas tendências a valorização/desvalorização.

De tal modo, em primeiro lugar (i), pode-se observar que

[...] A acumulação de ativos ou passivos promove igualmente a criação e distribuição de uma outra substância, mais dificilmente mensurável (e cujo nome é quase um tabu entre economistas), e que vem a ser o poder político [...]. (SILVA; SANTOS, 2008, p. 15).

Por conseguinte, pode-se considerar que a acumulação de um passivo externo líquido elevado significa por si só o aumento da vulnerabilidade externa, já que implica diminuição do poder efetivo e, geralmente, perda de autonomia na política econômica.

Dessa maneira, é importante analisar o que leva à formação de uma PII desfavorável. Alguns autores atribuem o aumento do passivo externo líquido (PEL1) a um excesso de gasto doméstico sobre a renda doméstica:

Em particular, o PEL1 se eleva se, e somente se, a absorção líquida de bens e serviços de certa economia se mostra, durante o período contábil em questão, superior ao Produto Nacional Bruto (PNB) medido a preços de mercado. Ou, equivalentemente, se o país absorve poupança externa, investindo mais do que poupa internamente. (CYSNE, 2008, p. 4).

Há inclusive autores que associam os déficits em transações correntes de um país a um excesso de gastos públicos, configurando a tese dos "déficits gêmeos" (e.g. CHINN; PRASAD, 2003; IMF, 2005).

Entretanto, nem todos os economistas enfatizam que um déficit em transações correntes significa um excesso de investimento sobre a poupança, tampouco destacam o excesso de demanda interna sobre a oferta doméstica. Em determinados contextos, um país pode inclusive ter superávits comerciais, mas, em função 
do pagamento de juros - ou demais pagamentos de rendas - incorrer em déficits em transações correntes (CARNEIRO, 2002). Ademais, como indica Cruz (1995), o recurso ao capital estrangeiro não deve ser visto como uma resposta automática com relação a um hiato de recursos; o acesso a esses recursos guarda estreita relação com as políticas nacionais regulatórias ou incentivadoras dessa prática e, claro, com o contexto internacional - notadamente o estágio dos ciclos de liquidez internacional (BIANCARELI, 2007).

As visões supracitadas destacam aspectos diferentes, atribuindo ao déficit das transações correntes sentidos muito distintos: Cysne (2008) e os teóricos dos "déficits gêmeos" enfatizam um excesso de gastos sobre a renda, enquanto Carneiro (2002) e Davidoff (1995) percebem que as rendas líquidas enviadas ao exterior podem ser muito importantes na análise desse déficit.

Desta maneira, parece fundamental analisar a identidade obtida em Araújo (2008):

$$
\mathrm{RD}=\mathrm{Y}-\mathrm{RL}=\mathrm{PNB}
$$

na qual RD é a renda doméstica, Y é o produto, RL é a renda líquida enviada ao exterior, e PNB é o produto nacional bruto.

Como fica evidente em Cysne (2008), o déficit nas transações correntes só ocorrerá se a absorção de bens e serviços for superior ao Produto Nacional Bruto (PNB). Contudo, o ponto que se tenta destacar, por meio da identidade (7), é que o PNB é afetado pela renda líquida enviada ao exterior (RL). Ou seja, nas diversas análises - e.g. Garcia (2001) - que se referem a uma "insuficiência de poupança doméstica" como a causa do desequilíbrio das transações externas, não se encontra a devida ênfase na "despoupança" causada pela RL. Essa discussão não é um mero manuseio de identidades, já que suas implicações são muito importantes: quando se tratam os déficits nas transações correntes unicamente como um excesso de investimento sobre poupança, gera-se a impressão de que a economia em questão é "perdulária" - vide o receituário de melhoria das contas externas preconizado pelo FMI, que passa pela moderação dos gastos.

Entretanto, a PII negativa (passivo externo líquido desfavorável) tende por si só a gerar uma "fuga/transferência de excedente" da economia doméstica para a estrangeira, por meio dos pagamentos dos fluxos de rendas gerados por esses estoques externos, autorizando a hipótese de que a PII desfavorável esteja, em algum grau, na causa da mencionada "insuficiência de poupança doméstica", não sendo apenas sua consequência.

Portanto, atentando-se para esse impacto que a interação entre a PII e as rendas líquidas enviadas ao exterior exerce sobre a vulnerabilidade externa, o enfoque da discussão passa a ser outro, já que esses rendimentos decorrentes dos estoques de ativos e passivos externos assumem protagonismo na explicação da 
permanente necessidade de geração de divisas, e da persistente perda de recursos por parte dos países deficitários em rendas, acentuando - ou até mesmo causando - a situação de "insuficiência de poupança". A ideia implícita nesse raciocínio é de que as entradas de divisas ocasionadas pelos financiamentos externos e as posteriores saídas por conta das amortizações e das rendas podem significar, intertemporalmente, uma perda líquida de divisas.

Dessa forma, levando-se em conta o segundo aspecto mencionado acima (ii), deve-se considerar não apenas a magnitude dos valores acumulados dos estoques externos, mas também as suas rentabilidades. Esse aspecto é importante porque muitas análises (e.g. SIMONSEN; CYSNE, 2007) consideram uma taxa de remuneração sobre o saldo do passivo externo líquido, desconsiderando o diferencial de rentabilidade entre os estoques externos dos diversos países. ${ }^{5}$

Tal método é insuficiente para analisar a questão da vulnerabilidade externa, pois não leva em conta que o sistema monetário internacional é hierarquizado, determinando que os países periféricos tenham, em geral, taxas de juros maiores do que os centrais ${ }^{6}$ (CARNEIRO, 2008). Assim, os países do centro do sistema monetário internacional, tendo geralmente taxas de juros menores que os periféricos, podem ter um ativo externo menor que o passivo externo e ainda assim obter uma entrada líquida de rendas, devido a uma rentabilidade mais elevada daquele em relação a este.

Isso ocorreu, por exemplo, nos Estados Unidos em 2000, quando o país detinha um passivo externo maior que o ativo externo, mas, mesmo assim, recebeu uma entrada líquida de rendas em função do diferencial de rentabilidade entre seus ativos e passivos externos. ${ }^{7}$ Essa economia apresentou, portanto, o que aqui se chama de um efeito rentabilidade favorável.

Fica nítido, então, que a vulnerabilidade externa é crescente quando a rentabilidade do passivo externo aumenta e é decrescente com a elevação da rentabilidade do ativo externo. Assim, o diferencial entre essas deverá ser considerado nas análises, como se fará a seguir.

O terceiro aspecto mencionado anteriormente (iii) está ligado à possibilidade de os estoques externos mudarem de valor por variações de preços (efeito GDN), seja pelo tipo de ativo que os caracteriza, seja porque são denominados em moedas diferentes. Nesse sentido,

[...] como se sabe da experiência internacional, passivos denominados em moeda doméstica são bem mais confortáveis em momentos de crises

$5 \quad$ Para uma crítica dessa construção de Simonsen e Cysne (2007), ver Noije (2010).

6 Segundo De Conti (2011), as taxas de juros dos países periféricos pagam um prêmio pela iliquidez de sua moeda no âmbito internacional.

7 O ativo externo estadunidense somava US $\$ 3.488$ bilhões, enquanto seu passivo externo era de US $\$ 6.446$ bilhões, mas ocorreu uma entrada de rendas de US $\$ 353$ bilhões, enquanto as saídas foram de apenas US\$ 331 bilhões (DUMÉNIL; LÉVY, 2005, p. 96-97). 
externas, tendo em vista que seu valor de mercado em moeda estrangeira costuma reduzir-se automaticamente em tais situações [...]. (CYSNE, 2008, p. 4).

Dessa maneira, deve-se levar em conta a composição dos estoques externos na análise e pode-se considerar que quanto maior a proporção do passivo externo denominado em moeda doméstica menor será a vulnerabilidade externa resultante. Raciocínio parecido vale para o ativo externo e quanto maior a participação de ativos denominados em moedas centrais, menor tende a ser a vulnerabilidade externa - a política de acumulação de reservas internacionais se enquadra nessa lógica.

Percebe-se, então, a necessidade de olhar para os estoques externos, já que países com passivos externos maiores do que os ativos externos tendem a ser mais vulneráveis, sobretudo quando se engendra o efeito circular entre a PII e as rendas por ele geradas, que determinam um crescimento endógeno do passivo externo líquido, aumentando as necessidades de financiamento externo para cobrir o pagamento das rendas geradas pelos próprios estoques. Essa vulnerabilidade externa acaba se manifestando de forma mais acentuada nos momentos de escassez de liquidez em âmbito internacional, o que dificulta o financiamento que alimentava a mencionada circularidade, gerando a necessidade de obtenção de divisas na esfera real para pagamento das rendas. A situação se agrava quando o país tem que amortizar uma parte desses estoques.

Nesse contexto, a economia fragilizada que tenta gerar saldos positivos por meio da transferência de recursos reais ao exterior corre dois riscos principais: i) sofrer de ajustes recessivos, caso adote uma estratégia agressiva de diminuir a absorção interna para gerar um aumento das exportações líquidas; ii) conviver com pressões inflacionárias por conta de desvalorizações cambiais que visem aumentar a competitividade dos produtos domésticos - não se devendo descartar a possibilidade de a economia conviver com as duas situações simultaneamente. Adicionalmente, os países periféricos correm riscos muito maiores nessas situações, principalmente, pois os fluxos de capitais externos a eles direcionados tendem a ser pró-cíclicos, afluindo com maior intensidade nos momentos de prosperidade e refluindo rapidamente aos primeiros sinais de crise no cenário internacional ou nacional.

Finalmente, é fundamental apontar e esclarecer uma distinção entre o efeito circular e o de manifestação da vulnerabilidade externa. Por um lado, existe um movimento de circularidade entre fluxos e estoques que determina a evolução da PII, sendo que este movimento depende dos fluxos de capitais externos, de forma que uma vulnerabilidade potencial é causada por essa dependência em relação ao financiamento externo. Assim, a evolução da PII, na sua dinâmica de circularidade, "independe" das transferências de recursos reais ao exterior (balança co- 
mercial e de serviços), que apenas amenizam ou acentuam a dinâmica, em casos de, respectivamente, superávits ou déficits. ${ }^{8}$ Além disso, a circularidade pode ser funcional durante certo período de tempo, já que as entradas de capitais externos podem estimular a economia doméstica, deixando, todavia, um rastro de passivos externos. Por outro lado, a manifestação aguda de problemas relacionados à vulnerabilidade externa não ocorre permanentemente, isto é, em apenas alguns períodos ela causará constrangimentos à economia doméstica, contudo, estas manifestações de vulnerabilidade são drásticas, pois envolvem não só os pagamentos das rendas como possíveis amortizações ou saídas de investimentos, o que tende a gerar crises nos países que passam por esta situação.

\section{Conjuntura Internacional e Políitica Econômica Interna do Período}

Esta seção apresenta um resumo de alguns dos principais movimentos da economia mundial e das políticas econômicas internas no período marcado pela crise da dívida externa no Brasil na década de 1980, privilegiando os acontecimentos que influenciaram as transações externas brasileiras e determinaram as condições de obtenção de divisas, seja pelo saldo comercial, seja pela atração de recursos externos. Para tanto, a primeira parte trata da conjuntura internacional e a segunda das políticas brasileiras no período.

\subsection{Conjuntura Internacional}

Nesta subseção, aponta-se para algumas das transformações da economia capitalista no pós-guerra e a origem dos desequilíbrios globais na década de 1970 , com destaque para o papel hegemônico dos Estados Unidos e as relações hierárquicas no sistema econômico internacional. Com o fim da segunda guerra mundial, esse país - abandonando as hesitações que caracterizaram sua política externa no entre guerras - resolveu seguir uma estratégia para se tornar uma potência hegemônica, em contraposição ao bloco comunista, criando uma nova ordem mundial marcada pela bipolaridade. A nova divisão internacional do trabalho com o crescente deslocamento das empresas americanas para os países europeus e asiáticos - acabou forçando a economia americana a aumentar seu grau de abertura comercial, gerando déficits comerciais para acomodar o aumento de produção desses países (TAVARES; BELLUZZO, 2005).

Nesse contexto, ocupa lugar de destaque o acordo de Bretton Woods, que conferiu o poder de emissor da moeda reserva do sistema aos Estados Unidos. Os principais objetivos americanos eram: a) o financiamento dos seus custos milita-

8 Evidentemente, caso os superávits ou déficits na balança comercial e de serviços sejam muito expressivos, a lógica de circularidade entre a PII e as rendas fica em segundo plano. 
res; b) a expansão da indústria americana por meio da empresa transnacional; c) a expansão internacional do sistema financeiro americano. Tais objetivos fizeram com que o país exercesse um papel de "regulador" do sistema capitalista global, provendo a liquidez necessária e representando uma fonte autônoma de demanda efetiva. Assim, acabou permitindo aos demais países a prerrogativa da utilização de políticas keynesianas de estímulo a suas economias (BELLUZZO, 2006).

Além disso, é de se destacar que o próprio sucesso da política de Bretton Woods - e as elevadas taxas de crescimento decorrentes de um contexto de fortes regulações - acabaram estimulando o processo de liberalização dos mercados financeiros domésticos, com transformações para permitir uma maior liberdade de capitais e a volta da hegemonia financeira. ${ }^{9} \mathrm{O}$ longo período de crescimento do produto e de melhorias sociais nos países centrais associou-se com o aumento da concorrência intercapitalista (pelo fortalecimento das empresas dos países outrora devastados pela guerra) e, ao fim, com um acirramento do conflito distributivo (BELLUZZO, 1997).

Assim, na década de 1970 o "pacto" entre Estado, trabalhadores e detentores de riqueza começou a ruir, com o início de um movimento de diminuição da participação do governo na economia. Isso num contexto de aumento da inflação e do surgimento de um ramo financeiro desregulamentado e com crescente capacidade de criação de crédito, facilitada pelas inovações financeiras, mas também pela reciclagem dos chamados petrodólares. A criação do Euromercado potencializou o movimento de internacionalização do sistema financeiro, com expressivo aumento dos empréstimos aos países periféricos. No bojo dessas transformações, observa-se o aumento do endividamento público, redundando num aumento da dependência do governo em relação ao capital financeiro.

O padrão de financiamento externo que sustentara por mais de uma década o crescimento econômico com regime de moderada inflação na América Latina começou a ruir no ano de 1979, quando o Federal Reserve começou a adotar uma rígida política monetária, tendo em vista estabilizar a economia americana e defender o papel do dólar como moeda hegemônica. Esse choque veio em dose dupla: primeiro a elevação das taxas de juros americanas; logo depois, o reajuste dos preços do petróleo (BELLUZZO; ALMEIDA, 2002).

Dessa maneira, a ameaça de degeneração do papel do dólar como reserva de valor do sistema monetário internacional e o consequente lançamento da política do dólar forte no final dos anos 1970 acabaram gerando: a) transformação da dinâmica da economia mundial, por meio da redistribuição da capacidade produtiva em termos globais; b) duradouros desequilíbrios no balanço de pagamentos

9 O autor aponta que esse capitalismo contemporâneo revela de forma mais verdadeira sua própria essência, com a revolução constante dos meios de produção, degradação das relações sociais e permanente incerteza (BELLUZZO, 2006). 
americano; c) avanço da globalização financeira (acentuando a tendência rentista do capitalismo, aumentando as assimetrias e piorando a distribuição de renda entre as classes sociais); e d) crise de liquidez para os países periféricos, inclusive o Brasil (aspecto fundamental para a análise deste trabalho) (TAVARES; BELLUZZO, 2005).

Esses fatores criaram sérios constrangimentos para as economias periféricas no início da década de 1980, redundando na moratória mexicana em 1982, que encerrou o financiamento dos países periféricos em moeda estrangeira, realizado pelos bancos comerciais internacionais. A partir de então, predominaram as políticas patrocinadas pelo FMI de ajustamento dos balanços de pagamentos dos países devedores, com o intuito de evitar o colapso dos sistemas bancários internacionais. Esses programas conseguiram resultados rápidos na redução dos déficits de transações correntes dos países devedores. Entretanto, um fator fundamental para isso foi a recuperação econômica dos EUA a partir do final de 1982, apoiada na queda dos juros e em um déficit público significativo, que gerou uma demanda elevada para o resto do mundo e permitiu que os países devedores obtivessem expressivos superávits comerciais (BELLUZZO; ALMEIDA, 2002).

\subsection{Políticas Internas}

Desde o início do processo de substituição de importações (PSI), o estrangulamento externo que caracterizou episodicamente a economia brasileira entre as décadas de 1930 e 1970 desempenhou um papel decisivo na industrialização. Segundo Tavares (1972), nos momentos críticos de carência de divisas, geravam-se forças dinâmicas que impulsionavam o aprofundamento do PSI, permitindo que se superassem temporariamente as restrições externas, até que sobreviesse nova crise externa.

Durante a década de 1970, a despeito dos impactos desfavoráveis sobre as contas externas relacionados ao primeiro choque do petróleo (1973), não houve maiores problemas para que o Brasil desse continuidade e até mesmo avançasse de forma decisiva a internalização dos setores de bens de capital e insumos intermediários.

Os dois violentos choques externos sofridos pela economia mundial no final dos anos 1970 (segundo choque do petróleo e choque dos juros americanos) inviabilizaram totalmente o esforço promovido por Delfim Netto de "reeditar" o "milagre econômico" brasileiro, como ele vinha tentando fazer desde agosto de 1979, quando assumiu novamente o comando da economia.

Em vista da imposição de limites e exigências rígidas para a rolagem da dívida externa brasileira a partir do último trimestre de 1980 e sobretudo a partir de setembro de 1982, com a suspensão abrupta dos financiamentos externos em 
virtude da moratória mexicana, o governo brasileiro viu-se constrangido a adotar rigoroso programa de estabilização externa, lastreado essencialmente na redução abrupta da absorção doméstica, visando à constituição de elevados superávits na balança comercial.

A partir dos últimos meses de 1980, a economia brasileira, que vinha apresentando trajetória de crescimento elevado (expansão de 6,8\% em 1979 e 9,2\% no ano seguinte) entrou num processo recessivo agudo, com queda do PIB de 4,2\% em 1981, relativa estagnação no ano seguinte $(0,8 \%)$ e nova rodada recessiva em 1983, com queda de $2,9 \%$ do PIB. Nesses três anos, a renda per capita declinou, em termos reais, $12,4 \%$, com óbvias repercussões negativas sobre a pobreza e a distribuição de renda. O determinante principal dessa situação estava relacionado à crise da dívida externa. O acúmulo expressivo de passivo externo nos anos precedentes ${ }^{10}$ tornou inevitável a adoção de políticas recessivas no início dos anos 1980. Tais políticas tiveram que ser mais severas, já que até o início de 1983 a economia mundial encontrava-se em recessão, dificultando o desempenho do setor exportador.

O governo fez uso de praticamente todos os instrumentos de que dispunha para restringir a demanda agregada: contenção salarial (alterando a legislação salarial vigente), controle de gastos, aumento da arrecadação (subcorreção das faixas do imposto de renda, aumento do IOF), elevação das taxas de juros (promovendo-se sua liberação, à exceção da parcela do crédito destinado ao setor agrícola e às exportações) e violenta contração da liquidez real (CARNEIRO; MODIANO, 2014, p. 264-267). Além disso, em fevereiro de 1983, promoveu uma maxidesvalorização de 30\% da taxa de câmbio, visando alterar de forma rápida e substancial os preços relativos entre a produção voltada para o mercado doméstico e para o mercado internacional.

Todo esse empenho repercutiu favoravelmente sobre a balança comercial. Todavia, o incremento observado na conta de juros relacionados à dívida externa tornou o ajuste muito mais penoso.

Para que se delineie uma ideia clara do processo, torna-se indispensável, antes da análise do desempenho das contas externas no período 1980-1984, uma referência à evolução dos gastos associados aos juros da dívida externa brasileira. O Gráfico 1 mostra essa evolução nas décadas de 1970-1980.

10 Notadamente, em função dos investimentos realizados durante os governos militares. 
Gráfico 1 - Juros da dívida externa (US\$ milhões) e Relação juros/exportações (\%) - Brasil (1970-1990)

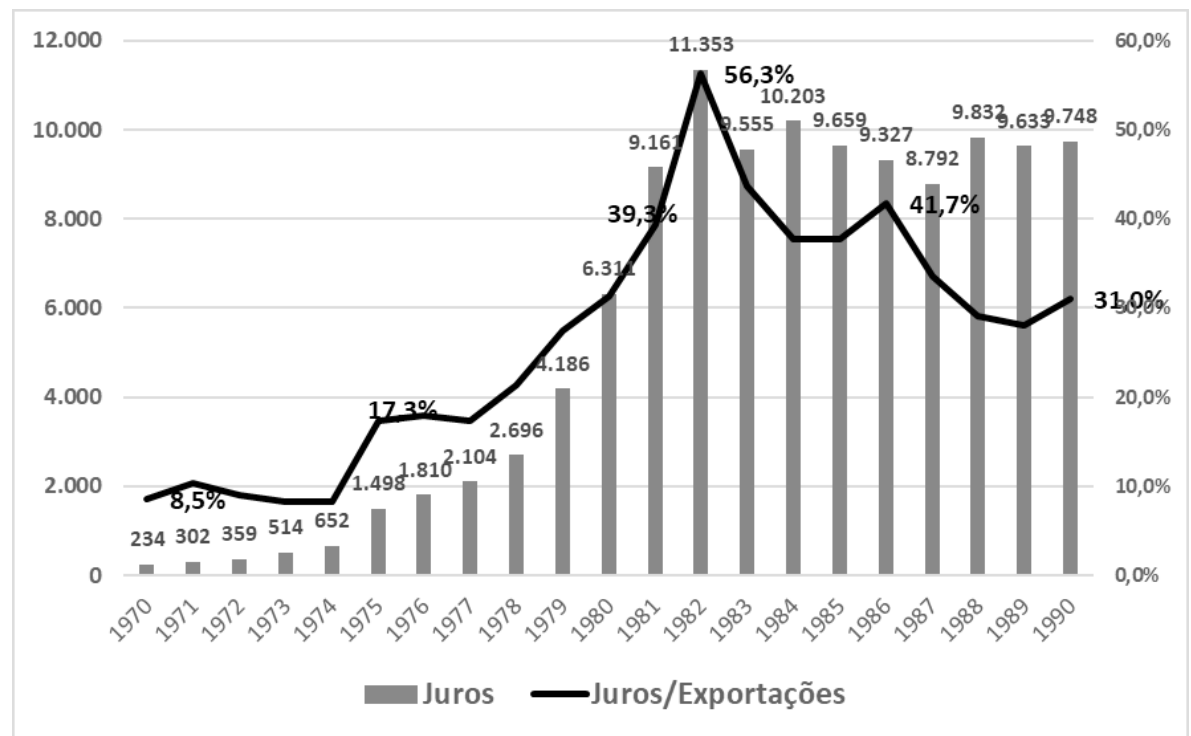

Fonte: Banco Central do Brasil (2017).

Se no início dos anos 1970 o pagamento líquido de juros era de US\$234 milhões, oito anos depois esse valor já tinha se multiplicado mais de onze vezes, alcançando US\$2,7 bilhões. Daí em diante, até 1982, a elevação dessa despesa mostrou-se ainda mais vigorosa, chegando a mais de US\$11,3 bilhões. Com a mudança da postura do FED, reduzindo a rigidez da política monetária a partir do segundo semestre de 1982 (LARA RESENDE, 1983, p. 48), houve algum alívio para as contas externas brasileiras nesse quesito, mas, como mostra o gráfico, os valores despendidos se mantiveram, até 1990, em níveis quase sempre próximos a US\$ 10 bilhões anuais. A curva apresentada no mesmo gráfico mostra que a relação entre os juros pagos e o total das exportações cresceu de forma substancial até o início da década de 1980, particularmente no período 1978/1982, no momento de maior aumento da taxa de juros norte-americana. Nesse último ano, os juros da dívida externa consumiram mais de metade do valor das exportações. Tal percentual reduziu-se nos anos seguintes de forma praticamente contínua, alcançando cerca de 30\% no final da década, um nível ainda três vezes superior ao verificado na primeira metade dos anos 1970.

A estes valores, acrescem-se as despesas relacionadas às remessas de lucros e dividendos (cuja média anual, entre 1980 e 1990, foi de US\$ 1,7 bilhão) e o saldo, sempre negativo, da conta de serviços (média de US\$2,6 bilhões). 
Como, a partir da moratória mexicana, o Brasil ficou marginalizado do sistema financeiro internacional, o financiamento dessas contas deficitárias passou a depender, fundamentalmente, dos saldos obtidos na balança comercial.

Em virtude das políticas acima enunciadas - e também da maturação de parte dos investimentos do II Plano Nacional de Desenvolvimento (CASTRO; SOUZA, 1985) - já em 1981 o déficit de US $\$ 2,8$ bilhões de 1980 transformou-se num superávit de US $\$ 1,2$ bilhão. Todavia, o impacto sobre o saldo em conta corrente, que era mais importante do ponto de vista da redução da necessidade de novos financiamentos externos, revelou-se bem mais modesto, em vista do aumento substancial das despesas com juros, que se ampliou quase US $\$ 3$ bilhões nesse período (de US $\$ 6,3$ para US $\$ 9,2$ bilhões). O déficit em conta corrente reduziu-se apenas de US\$12,7 para US\$11,7 bilhões entre 1980 e 1981.

Por razões domésticas e internacionais, o saldo da balança comercial reduziu-se, em 1982, para US $\$ 780$ milhões, e exatamente nesse ano a conta de juros atingiu seu valor mais elevado na década (mais de US\$11,3 bilhões), fazendo com que o saldo negativo da conta corrente, considerando-se os outros itens negativos da conta de renda e serviços, atingisse o valor recorde de US $\$ 16,2$ bilhões. Em face de tal quadro, a perda de reservas internacionais, juntamente com a moratória mexicana de agosto de 1982, e a recusa em fazer uso da moratória, obrigou o governo brasileiro a recorrer ao FMI. Constrangido pelas condicionalidades impostas pelo Fundo, o governo brasileiro deu início a uma nova rodada de políticas contracionistas no âmbito fiscal, monetário e creditício, com profundos reflexos sobre a economia nacional no ano de 1983.

A queda do PIB foi de $2,9 \%$, com óbvios resultados negativos no que tange ao desemprego, pobreza e distribuição de renda. A conjugação desse processo recessivo com a maxidesvalorização da taxa de câmbio em fevereiro de 1983 e o início da recuperação da economia mundial no segundo semestre ensejou uma vigorosa reação da balança comercial, com seu saldo, de forma algo surpreendente, ultrapassando o valor fixado no acordo com o FMI (US\$ 6 bilhões), chegando a US $\$ 6,5$ bilhões. Com isso e com a queda das taxas de juros internacionais, o saldo negativo em conta corrente reduziu-se em quase US $\$ 10$ bilhões.

O denominado ajuste externo completou-se em 1984, quando a economia mundial, agora em plena recuperação, abriu espaço para um aumento de mais de US $\$ 5$ bilhões nas exportações, permitindo a constituição de um saldo de pouco mais de US\$ 13 bilhões na balança comercial, praticamente zerando o saldo da conta de transações correntes. É importante observar, no entanto, que isto não impediu que, em fevereiro de 1987, com um nível de reservas de "pouco mais de US $\$ 3$ bilhões, o equivalente a menos de três meses de importação" (BATISTA JÚNIOR, 1988, p. 29), o Brasil interrompesse por tempo indefinido o pagamento dos juros de parte substancial de sua dívida externa. A retomada dos pagamentos 
só ocorreria no final da década, quando da gestão de Maílson da Nóbrega à frente do Ministério da Fazenda.

Todavia, é fundamental chamar a atenção para o fato de que a conquista desse ajuste externo se fez à custa da geração de profundos desequilíbrios em alguns dos principais indicadores macroeconômicos internos, notadamente no que diz respeito à forte aceleração inflacionária, que, em pleno contexto recessivo, ascende do patamar de 100\% para 210\% ao ano entre 1981 e 1983, e ao expressivo aumento da dívida interna líquida como porcentagem do PIB. De fato, a crise da dívida externa conduziu "a economia brasileira a um quadro de estagnação, de crescente instabilidade macroeconômica e de inibição generalizada dos investimentos produtivos" (CRUZ, 1994, p. 75). A mesma ideia, formulada de forma mais enfática, pode ser encontrada em Carneiro (2002, p. 140):

A drástica redução do crescimento, a estagnação do produto per capita, a regressão do investimento e a transferência de recursos reais ao exterior são, assim, os pontos de destaque numa caracterização da década de 1980. Essas características, por sua vez, não podem ser tomadas como independentes entre si. Há entre elas uma hierarquia ou, mais precisamente, uma maior relevância da transferência de recursos reais como fator determinante da trajetória das demais variáveis econômicas.

Em suma, tendo em vista a necessidade premente de gerar elevados superávits comerciais para fazer frente aos encargos associados, sobretudo, ao acúmulo de expressivo saldo negativo na Posição Internacional de Investimentos nas décadas anteriores, o Brasil viu-se submetido à - até então - pior recessão desde a grande depressão dos anos 1930. A mudança da posição brasileira de receptor para exportador líquido de capitais para o restante do mundo, ocorrida nesse período, cobrou um alto preço para a maioria da população brasileira, com especial destaque para sua fração mais pobre.

Colocando de outra forma, pode-se dizer que a interrupção dos fluxos voluntários de financiamento externo, sobretudo após a moratória mexicana, exigiu uma reversão drástica das contas externas do país, fazendo com que o Brasil, até o final do governo Itamar Franco, se transformasse, na maior parte dos anos, em exportador líquido de poupança para o restante do mundo.

\section{Estimativa da Posição Internacional de Investimentos}

Nesta seção, pretende-se apresentar uma estimativa da Posição Internacional de Investimentos (PII) da economia brasileira para o período de 1980 a 1990. Vale ressaltar que não existem dados para a PII brasileira no período anterior a 2001, de forma que uma das contribuições dessa pesquisa é justamente apresentar as estimativas realizadas. 


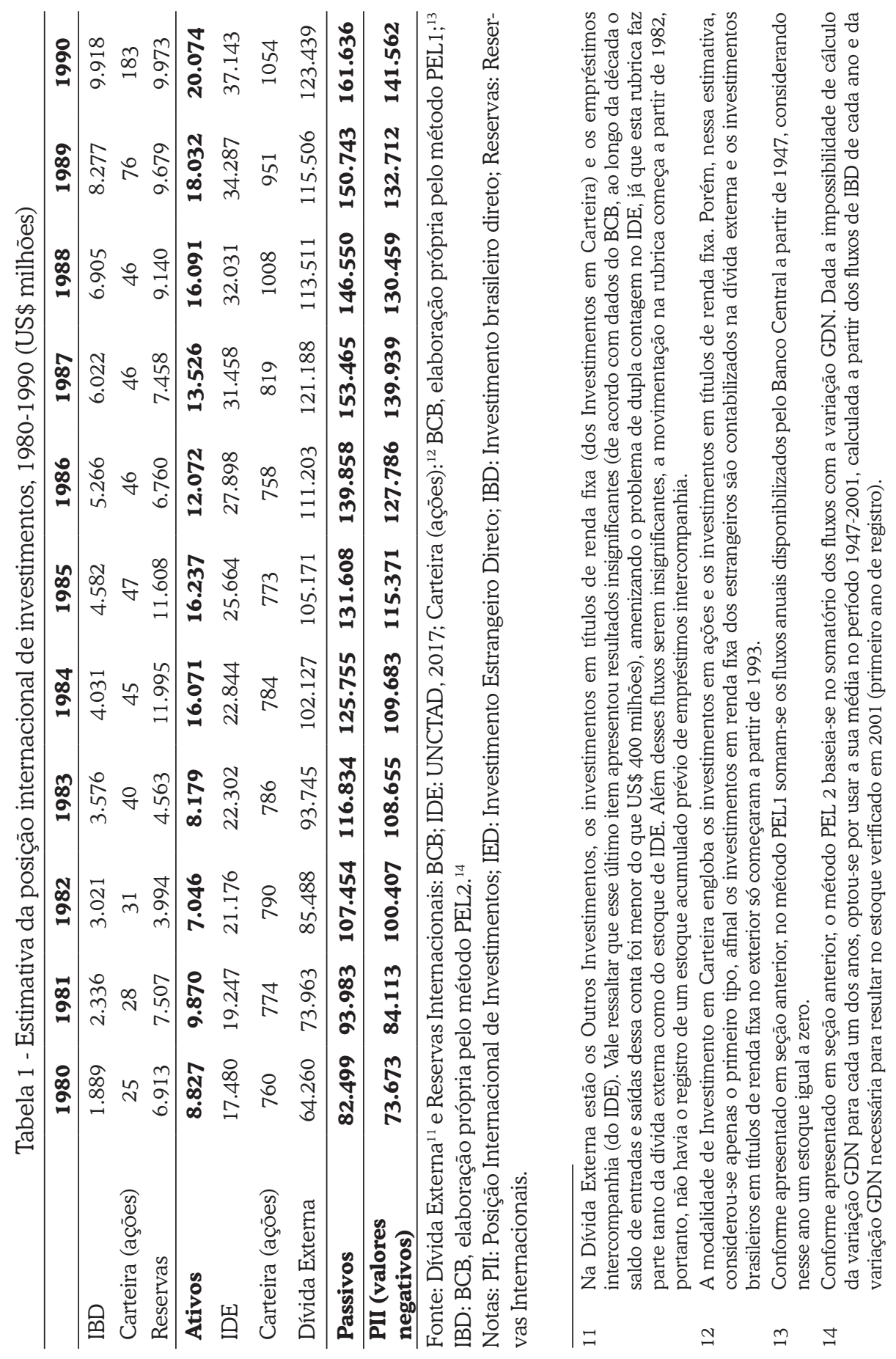


Os valores da PII da economia brasileira para o período de 1980 a 1990 são apresentados na Tabela 1, mostrando que o Brasil tem um passivo externo maior do que o ativo externo, podendo ser considerado mais vulnerável externamente, sob a ótica do presente estudo, por causa de sua condição patrimonial.

Pode-se observar que ao longo do período o ativo externo apresenta uma tendência de ligeiro aumento no seu valor. No entanto, o passivo externo tem um aumento muito maior, passando de US $\$ 82$ bilhões em 1980 para US $\$ 162$ bilhões em 1990 (Tabela 1). Como resultado, o passivo externo líquido (PEL), ou seja, o oposto da PII, varia de US\$ 74 bilhões para US\$ 142 bilhões durante o período 1980-1990.

Entretanto, apesar do aumento significativo do passivo externo, pode-se observar, pelo Gráfico 2, que sua composição permaneceu relativamente estável, com uma participação da dívida externa próxima de $80 \%$ da PII e o passivo denominado em moeda doméstica em torno de $20 \%$ da PII. Conforme apresentado em seção anterior, isso caracteriza uma elevada vulnerabilidade externa pela preponderância do passivo externo em moeda estrangeira.

Gráfico 2 - Composição do passivo externo brasileiro (\%), 1980-1990

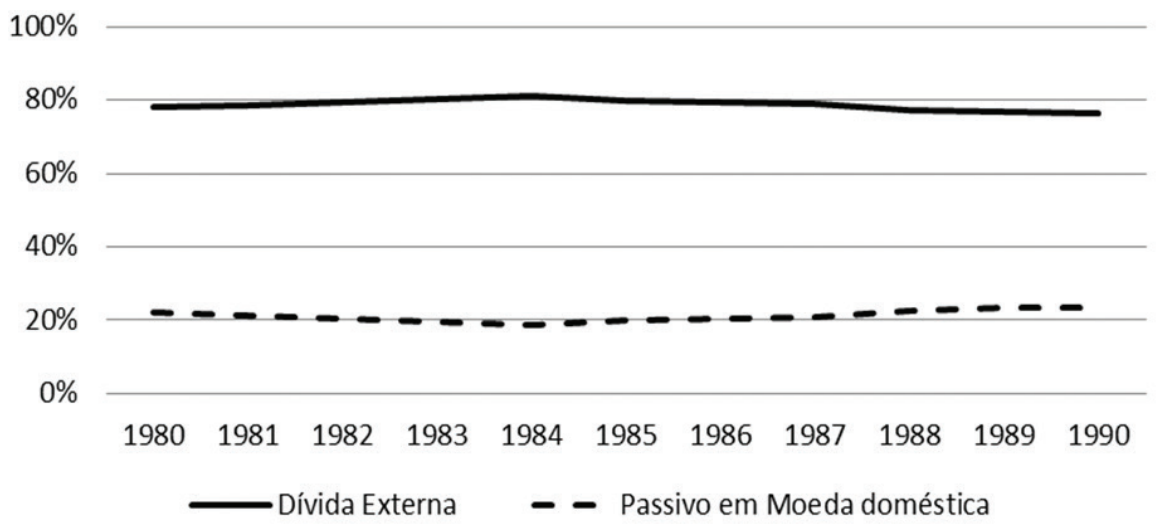

Fonte: Elaboração própria a partir de dados da Tabela 1.

Notas: (1) Passivo em moeda doméstica = estoque de investimento direto estrangeiro e de carteira (ações) 
Tal situação foi potencializada pelo nível das reservas internacionais, que se manteve num patamar relativamente baixo (sem passar dos US $\$ 12$ bilhões) ao longo do período, enquanto a dívida externa se elevou em termos absolutos (Tabela 1), de maneira que a dívida externa líquida aumentou consideravelmente no período - apesar de que em relação ao PIB ela aumenta somente até o ano de 1984 (Tabela 2).

Tabela 2- Indicadores de vulnerabilidade externa, 1980-1990

\begin{tabular}{|c|c|c|c|c|c|c|c|c|c|c|c|}
\hline & 1980 & 1981 & 1982 & 1983 & 1984 & 1985 & 1986 & 1987 & 1988 & 1989 & 1990 \\
\hline Passivo & & & & & & & & & & & \\
\hline $\begin{array}{c}\text { Externo/ } \\
\text { PIB }\end{array}$ & 0,35 & 0,36 & 0,40 & 0,62 & 0,66 & 0,62 & 0,54 & 0,54 & 0,48 & 0,36 & 0,34 \\
\hline Dívida & & & & & & & & & & & \\
\hline $\begin{array}{l}\text { Externa/ } \\
\text { PIB }\end{array}$ & 0,27 & 0,29 & 0,32 & 0,49 & 0,54 & 0,50 & 0,43 & 0,43 & 0,37 & 0,28 & 0,26 \\
\hline Ativo & & & & & & & & & & & \\
\hline $\begin{array}{c}\text { Externo/ } \\
\text { PIB }\end{array}$ & 0,04 & 0,04 & 0,03 & 0,04 & 0,08 & 0,08 & 0,05 & 0,05 & 0,05 & 0,04 & 0,04 \\
\hline $\begin{array}{l}\text { Div. Ext. } \\
\text { Líquida/ } \\
\text { PIB }\end{array}$ & 0,24 & 0,26 & 0,30 & 0,47 & 0,48 & 0,44 & 0,41 & 0,40 & 0,34 & 0,25 & 0,24 \\
\hline PII/ PIB & $-0,31$ & $-0,33$ & $-0,37$ & $-0,57$ & $-0,58$ & $-0,55$ & $-0,50$ & $-0,50$ & $-0,43$ & $-0,32$ & $-0,30$ \\
\hline $\begin{array}{c}\text { PII/ } \\
\text { export. } \\
\text { de bens }\end{array}$ & $-3,7$ & $-3,6$ & $-5,0$ & $-5,0$ & $-4,1$ & $-4,5$ & $-5,7$ & $-5,3$ & $-3,9$ & $-3,9$ & $-4,5$ \\
\hline $\begin{array}{l}\text { PII/ } \\
\text { export. } \\
\text { de } \\
\text { serviços }\end{array}$ & $-44,2$ & $-38,9$ & $-57,7$ & $-66,5$ & $-58,7$ & $-56,7$ & $-71,1$ & $-71,9$ & $-57,8$ & $-42,5$ & $-37,7$ \\
\hline $\begin{array}{c}\text { PII/ } \\
\text { Reservas }\end{array}$ & $-10,7$ & $-11,2$ & $-25,1$ & $-23,8$ & $-9,1$ & $-9,9$ & $-18,9$ & $-18,8$ & $-14,3$ & $-13,7$ & $-14,2$ \\
\hline
\end{tabular}

Fonte: Elaboração própria com base em: a) PIB: BCB, pelo câmbio médio do ano; b) Dívida Externa, Reservas, exportações de bens e de serviços: BCB; c) Passivo Externo, Ativo Externo, IED, PII: Tabela 1.

Apresentam-se na Tabela 2 alguns indicadores de vulnerabilidade externa, obtidos pela utilização da estimativa da PII, com o intuito de analisar qual o efeito da política de transferir recursos reais ao exterior - através de saldos positivos na balança comercial - sobre as contas externas. Pode-se observar, por meio dos diversos indicadores mostrados na Tabela 2, a deterioração das contas externas brasileiras até meados da década de $1980,{ }^{15}$ sendo que a PII estimada durante

15 Nota-se, na Tabela 2, que o ano de 1984 foi o pior para três indicadores que são relacionados entre si, quais sejam, "Passivo Externo/PIB”, "Dívida Externa/PIB” e "Dívida Externa Líquida/PIB”. 
o período se elevou do patamar de $-31 \%$, em 1980, para $-58 \%$ do PIB $^{16}$ em 1984 , decorrente de um expressivo aumento da dívida externa e da queda do PIB. Entretanto, na segunda metade da década os indicadores melhoram. ${ }^{17}$ Se se considera que o esforço mais significativo para viabilizar o ajuste externo ocorreu na primeira metade da década, sobretudo entre 1981 e 1983, fica claro que este esforço, apesar de seu impacto negativo sobre os níveis de renda e emprego, mostrou-se bem menos importante que as mudanças favoráveis no contexto internacional a partir de 1984 (redução da taxa de juros americana, queda do preço do petróleo e retomada do crescimento da economia mundial).

\section{Rendas Líquidas Enviadas ao Exterior}

Conforme corroborado pela Tabela 3, as saídas de rendas sempre foram maiores, no Brasil, do que as entradas, caracterizando o déficit estrutural dessa conta. Como se nota, o valor das rendas líquidas enviadas aumenta substancialmente no período imediatamente após o ano de $1979,{ }^{18}$ ano do choque dos juros. No que diz respeito à saída líquida de outros investimentos, que reflete principalmente as despesas com juros da dívida externa, o saldo passa de US\$ 2,6 bilhões em $1978^{19}$ a quase US $\$ 4,2$ bilhões em 1979, continuando a subir até 1982, quando alcança mais de US\$10,6 bilhões. A partir de 1983, com a redução da taxa de juros americana, a conta de juros recua para um patamar em torno de US\$ 9 bilhões. Além dessa conta, a mais importante no período, pode-se destacar o montante das rendas provenientes do IDE, porém, grande parcela desta rubrica acabou por se constituir em reinvestimentos, ${ }^{20}$ não pressionando por geração de divisas.

Já os indicadores "Ativo Externo/PIB" e "Reservas/PII", que também são relacionados entre si, tiveram como pior momento o ano de 1982. Enquanto isso, os indicadores "PII/exportações de bens" e "PII/exportações de serviços" tiveram, respectivamente, como piores momentos, os anos de 1986 e 1987.

16 Deve-se ressaltar que a mensuração do PIB em dólares nesse período é muito problemática por conta das fortes oscilações da taxa de câmbio, assim, ganham relevância os indicadores que fazem a divisão da PII por fontes que podem ser utilizadas para o seu pagamento, como as exportações de bens e serviços e as reservas internacionais, que apontam para um aumento dessa relação até meados da década.

17 Os indicadores que têm o PIB no denominador começaram a melhorar a partir de 1985. Entretanto, os que têm a PII no numerador demoraram mais para melhorar; seguindo a linha de raciocínio usada neste artigo, isso se explica, pois a PII continuou se elevando ao longo de todo o período, isto é, o ajuste recessivo apenas amenizou a tendência.

18 Optou-se por construir a Tabela 3 a partir de 1979 justamente por conta do choque dos juros desse ano.

19 Dados não mostrados na Tabela 3, mas de acordo com dados do BCB.

20 Idem. 


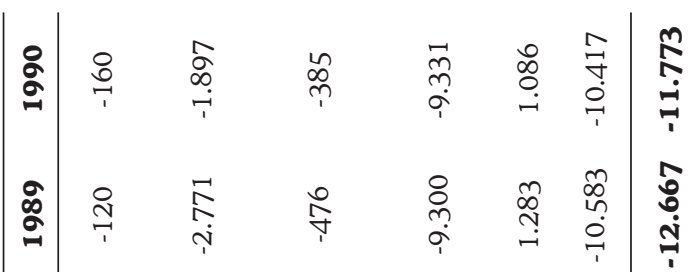

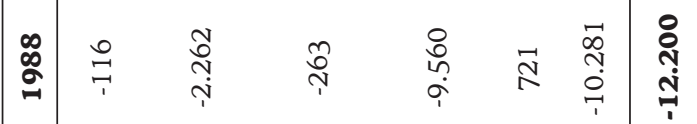

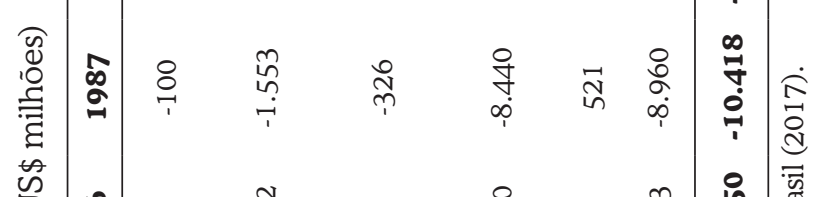

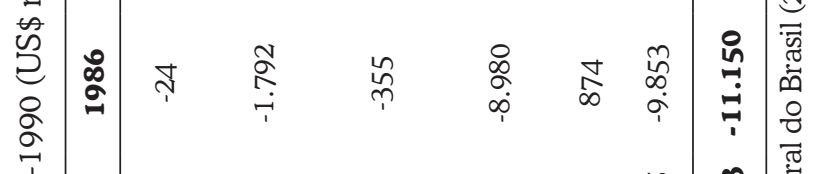

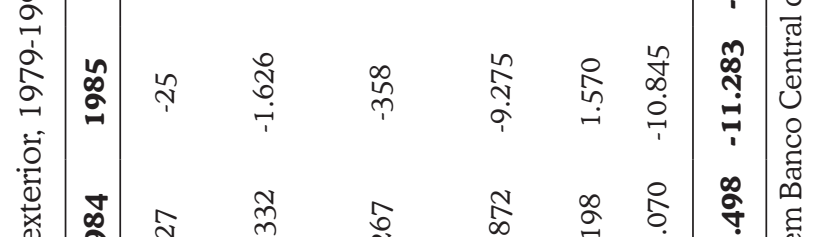

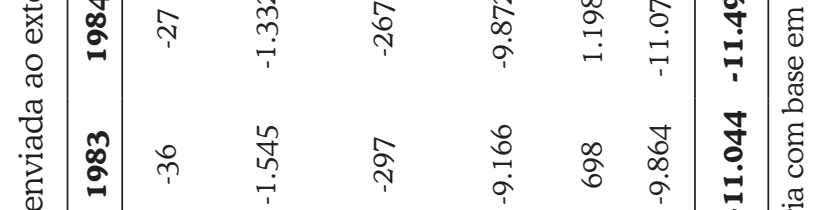

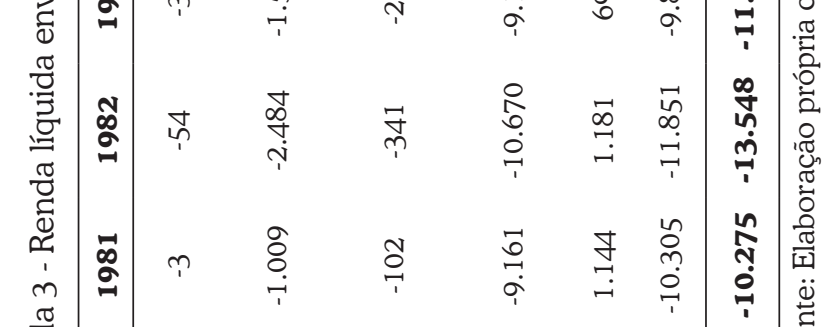

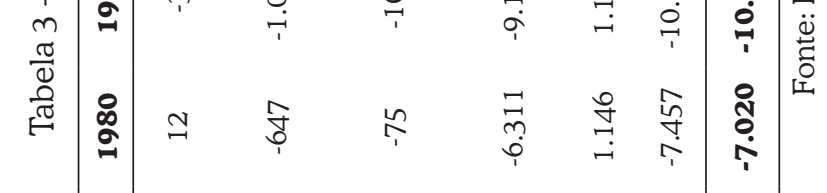

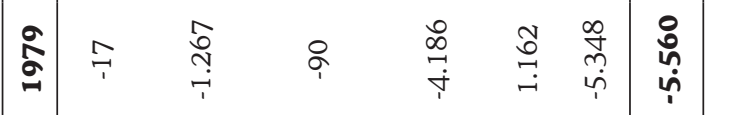

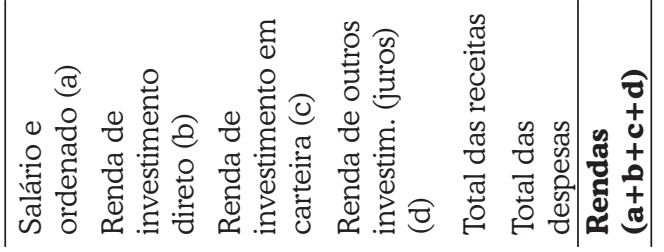


Vale salientar que a economia brasileira também recebeu rendas, com as entradas mais importantes ocorrendo pelos juros de outros investimentos, decorrentes das reservas internacionais, e pelo choque dos juros de 1979, que beneficiam as entradas nessa conta (de acordo com dados do Banco Central do Brasil, no ano de 1978 essa rubrica apresentou uma entrada de US\$ 647 milhões, que passou para US\$ 1.162 milhões no ano seguinte).

\section{Estimativa da Rentabilidade da PIl e alguns Indicadores de Endividamento Externo.}

Após a apresentação da estimativa dos estoques dos passivos e ativos externos da economia brasileira no período 1980-1990 e da análise dos fluxos de rendas gerados pelos mesmos, é possível estimar a rentabilidade aparente da PII e de suas diversas contas. Para tanto, a metodologia adotada consiste na divisão entre os fluxos de rendas de uma determinada conta durante um ano e o valor do estoque dessa conta no final do mesmo ano. ${ }^{21}$

Pode-se considerar, conforme apresentado em seção anterior, que a vulnerabilidade externa na esfera financeira se encontra diretamente relacionada com a rentabilidade do passivo externo, ou seja, quanto maior essa rentabilidade, mais vulnerável externamente essa economia tende a ser. ${ }^{22} \mathrm{O}$ inverso ocorre com a rentabilidade do ativo externo.

Dessa maneira, de acordo com a Tabela 4, pode-se observar algumas características da estimativa da rentabilidade da PII. Em primeiro lugar, em função da hierarquia das moedas, ${ }^{23}$ espera-se que a rentabilidade do ativo externo seja menor do que a do passivo externo, afinal, países que detêm moedas periféricas, como é o caso brasileiro, só conseguem atrair capitais estrangeiros caso ofereçam uma alta rentabilidade. Entretanto, nos anos de 1980 e 1982, a rentabilidade estimada do ativo externo $(1980=15,9 \% ; 1981=14 \% ; 1982=21,1 \%)$ foi consideravelmente maior do que a do passivo externo $(1980=10,2 \% ; 1981=12,4 \% ; 1982$ $=14,0 \%$ ), em função da forte elevação das taxas de juros nos EUA e da decorrente crise que eclode na economia brasileira. Apesar disso, quando se analisa a década como um todo, pode-se considerar que a economia brasileira teve uma vulnerabilidade externa sob a ótica do efeito rentabilidade, afinal, na maior parte dos outros anos da série - e, sobretudo, nos últimos - a rentabilidade do passivo externo foi significativamente maior do que a do ativo (de 1983 a 1990, apenas em 1985 isso

21 Ou seja, RENTABILIDADE = FLUXO anual da conta X / ESTOQUE ao final do ano da conta X.

22 Contudo, tal análise deve levar em conta também o tamanho e a composição dos estoques dos passivos externos.

23 Para detalhes, ver Prates (2002) e Carneiro (2008). 


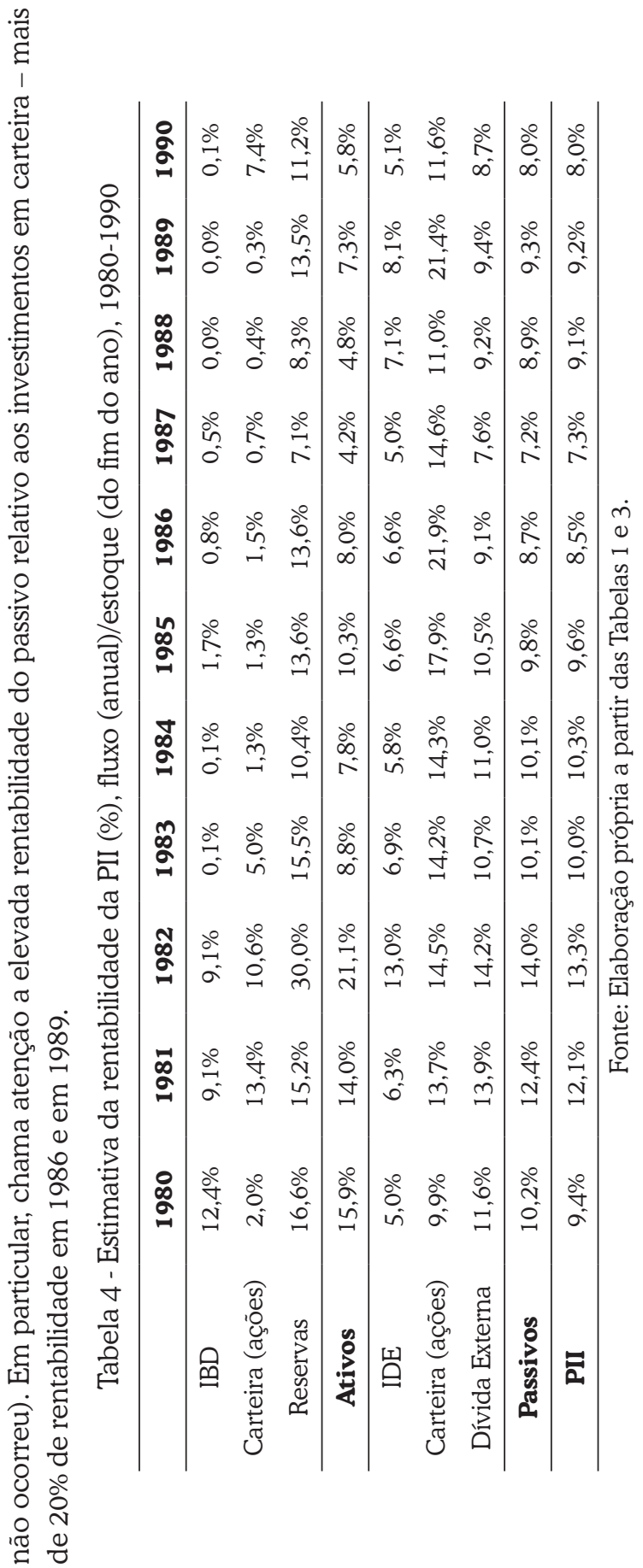


Em segundo lugar, percebe-se que a rentabilidade aparente da dívida externa (e das reservas) foi sempre maior do que a do IDE (e do IBD). Por exemplo, em 1984 a Dívida Externa teve rentabilidade de 11,0\% e o IDE de apenas 5,8\%. Esse resultado não é trivial, já que o fato de o estoque de IDE se desvalorizar conjuntamente com o câmbio sugere que os investidores demandariam uma rentabilidade maior para manter esse tipo de investimento, como um prêmio contra o risco cambial. Entretanto, dois aspectos podem explicar o ocorrido: em primeiro lugar, a excepcionalidade do momento, com o expressivo aumento das taxas de juros no âmbito internacional, que aumentou a rentabilidade da dívida externa (e das reservas internacionais); em segundo lugar, pela estratégia das empresas multinacionais de se instalarem nos países periféricos - conforme seção 4 -, evitando as barreiras comerciais impostas às importações nesses países, aceitando assim uma rentabilidade momentaneamente menos elevada.

Na Tabela 5 são apresentados diversos indicadores de endividamento externo, que são utilizados pelo BCB para fazer análises para períodos mais recentes. Dessa maneira, a disponibilização dos valores de tais indicadores para períodos anteriores é um passo importante para o aprofundamento do debate em relação à situação externa da economia brasileira.

Pode-se perceber que os indicadores do grupo A (Tabela 5) apresentam uma significativa deterioração até o período 1982-1983, aumentando, ${ }^{24}$ para iniciarem um movimento de queda no fim do período. Nota-se que os juros/exportações representam aproximadamente 0,6 em 1982, caindo já a partir de $1983 .{ }^{25}$ Além disso, pode-se perceber que, dentro desse contexto de piora da vulnerabilidade externa no início da década, as exportações se recuperaram mais rapidamente do que o PIB - de acordo com a Tabela 2, os indicadores só melhoraram a partir de 1985. Já os indicadores do grupo B também apresentaram uma significativa deterioração no início da década, diminuindo de valor. Entretanto, "Reservas/juros", que apresentou o valor mais baixo em 1982, de 0,35, já melhorou em 1983, obtendo 0,48, enquanto "Reservas/dívida total" melhorou em 1984 e 1985, ficando em torno de 0,11, e voltando a ficar em um patamar menor ao longo da década.

24 O aumento dos indicadores no Grupo A e a diminuição dos indicadores no grupo B representam um aumento da vulnerabilidade externa.

25 Os indicadores "Dívida externa/exportações" e "Dívida líquida/exportações" caíram a partir de 1984. 
Tabela 5 - Diversos indicadores de endividamento externo, 1979-1990

$\begin{array}{lllllllllll}1980 & 1981 & 1982 & 1983 & 1984 & 1985 & 1986 & 1987 & 1988 & 1989 & 1990\end{array}$

\section{A-) Juros e divida total}

$\begin{array}{cccccccccccc}\begin{array}{c}\text { Juros/ } \\ \text { exportações }\end{array} & 0,3 & 0,4 & 0,6 & 0,4 & 0,4 & 0,4 & 0,4 & 0,3 & 0,3 & 0,3 & 0,3 \\ \begin{array}{c}\text { Dívida total/ } \\ \text { exportações }\end{array} & 3,2 & 3,2 & 4,2 & 4,3 & 3,8 & 4,1 & 5,0 & 4,6 & 3,4 & 3,4 & 3,9 \\ \begin{array}{c}\text { Dívida } \\ \text { líquida total/ } \\ \text { exportações }\end{array} & 2,8 & 2,9 & 4,0 & 4,1 & 3,3 & 3,6 & 4,7 & 4,3 & 3,1 & 3,1 & 3,6\end{array}$

B-)

\section{Reservas}

Reservas

(liquidez)/ juros

\section{$1,10 \quad 0,82$}

0,35

0,48

$1,18 \quad 1,20$

0,72

0,85

$0,93 \quad 1,00 \quad 1,02$

Reservas

(liquidez)/

dívida total

$0,11 \quad 0,10$

0,05

0,05

0,12

0,11

0,06

0,06

0,08

$0,08 \quad 0,08$

\section{C-)}

Transações correntes/

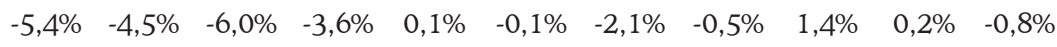
PIB

Fonte: Elaboração própria com base em Banco Central do Brasil (2017).

Um dos indicadores mais utilizados para avaliar as contas externas, no Grupo C, é o saldo em transações correntes em relação ao PIB. Observa-se que os déficits em transações correntes foram bastante elevados no início da década, chegando ao patamar de 6\% do PIB. Somente a partir de 1984, esses valores se aproximam de zero, permanecendo relativamente equilibrados até o final da década - ou seja, não obstante o enorme esforço para transferir recursos reais ao exterior, a economia não conseguiu gerar saldos positivos expressivos em transações correntes.

\section{Efeito Circularidade entre a Pll e as Rendas Líquidas enviadas num Con- texto de Manifestação da Vulnerabilidade Externa: 1980-1990}

Conforme apresentado em seção anterior, é fundamental distinguir o supracitado efeito circular - dos estoques com os fluxos externos - e o efeito de manifestação da vulnerabilidade externa. Sobre o primeiro, existe um movimento de circularidade 
entre fluxos e estoques que determina a evolução da PII, aspecto que depende das entradas líquidas de capitais externos, de forma que uma vulnerabilidade potencial é causada por essa dependência em relação ao financiamento externo. As outras contas - comercial e de serviços - apenas amenizam ou acentuam essa dinâmica. Em relação ao segundo, a manifestação da vulnerabilidade externa ocorre apenas em alguns períodos específicos, causando constrangimentos à economia doméstica, pois envolvem a retração dos financiamentos que alimentavam a circularidade, dificultando não só os pagamentos das rendas como das possíveis amortizações ou saídas de investimentos, o que tende a gerar crises. Logo, a ligação principal entre os dois aspectos é que o efeito circularidade cria as condições para que em algum momento a vulnerabilidade se manifeste. A atual seção analisará como a mencionada circularidade evoluiu em um contexto de manifestação da vulnerabilidade externa.

Como já aventado, o Brasil está no grupo dos países que, liquidamente, enviam renda para o exterior e o período em análise (1980-90) não foi diferente. Para piorar a situação, em poucos momentos desse período o Brasil obteve um saldo nas outras contas (comércio e serviços) suficiente para o pagamento das rendas enviadas, de forma que na maioria dos anos o país apresentou uma necessidade de financiamento do resto do mundo por conta de déficits em transações correntes.

Dessa maneira, pode-se considerar o Brasil na pior condição de vulnerabilidade externa, já que ele tem a necessidade de gerar divisas na balança comercial para o pagamento de rendas, mas, geralmente, esse superávit revelou-se insuficiente para reduzir o saldo negativo da PII. Sugeriu-se em seção anterior que os países nessa situação tendem a adaptar sua inserção externa a essa condição. Dado o contexto de manifestação da vulnerabilidade externa, o país parece ter utilizado todos os instrumentos disponíveis em prol do objetivo de transferir recursos reais ao exterior para servir os encargos do passivo externo.

Portanto, considera-se que o período analisado se caracterizou como de manifestação da vulnerabilidade externa decorrente da PII e do fluxo de rendas associado. De tal modo, resta analisar como essa política com um forte viés contracionista afetou a circularidade entre a variação dos estoques externos (PII) e as rendas líquidas enviadas ao exterior, buscando ponderar se o país ampliou ou não a sua vulnerabilidade externa.

Foi feita uma estimativa dos fatores que levaram à variação anual da PII, comparando essa variação com o saldo das transações correntes. A diferença de valor entre essas duas variáveis (variação anual da PII e saldo anual das transações correntes) foi atribuída, por simplificação, ao fator GDN ${ }^{26}$ Dessa maneira, por exemplo, em 1983, nota-se pela Tabela 6 que a variação da PII foi de US\$-8.614 milhões, enquanto o saldo das transações correntes foi de US $\$-6.773$ milhões, de

26 Apesar de também poder ser decorrente do efeito OMV que, no entanto, costuma ser menos significativo, como discutido na seção 2 . 


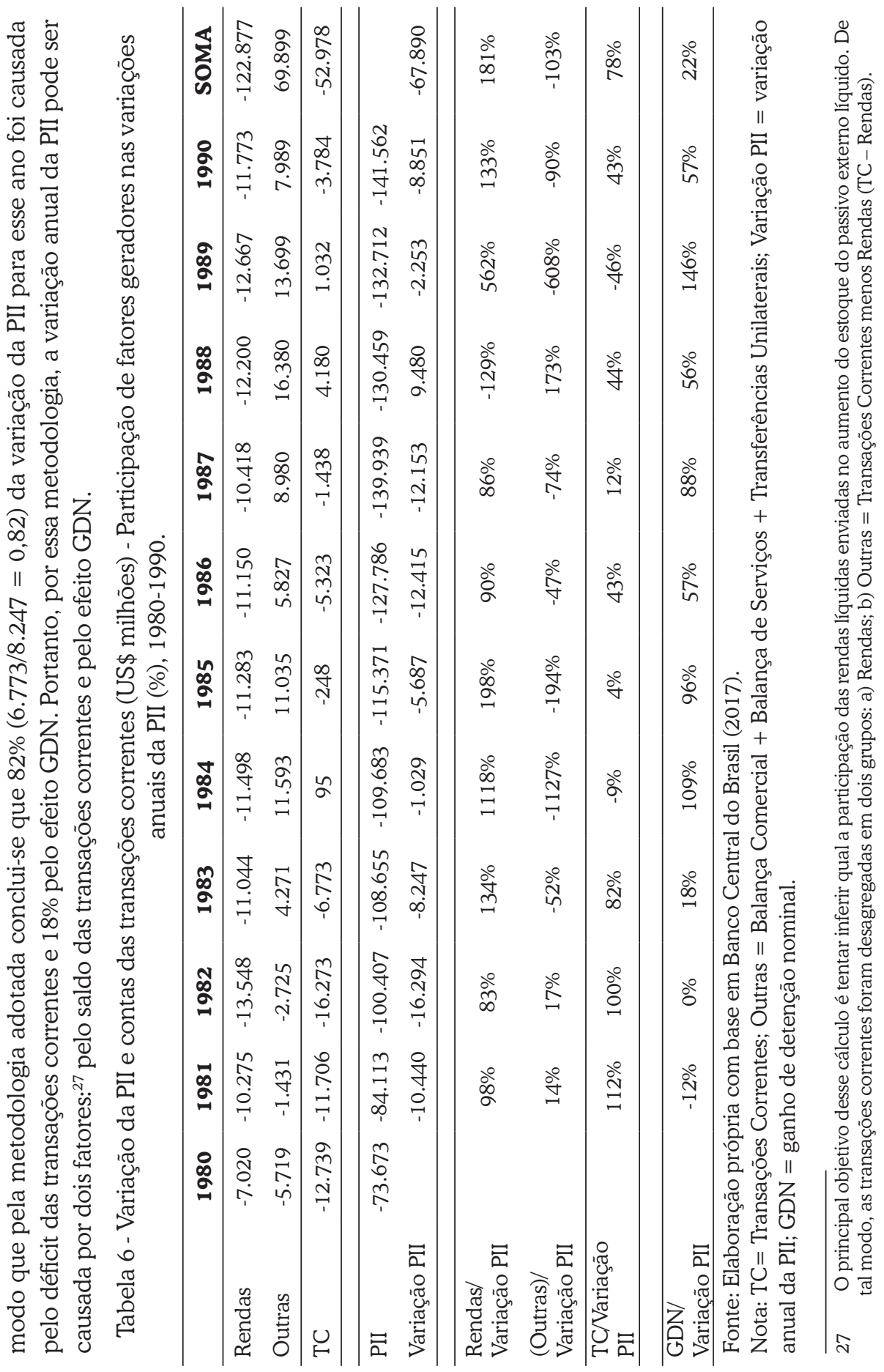


A tentativa de inferir qual a participação das rendas líquidas enviadas no aumento do estoque do passivo externo líquido é obtida pela relação Rendas/Variação anual da PII (pela Tabela 6, Rendas/Var PII). Com tal metodologia, chega-se à conclusão de que as rendas líquidas foram responsáveis, no período 1980-1990, por $181 \%$ da variação total da PII, um percentual extremamente elevado. O esforço de transferir recursos reais ao exterior contrabalançou as saídas de rendas, significando um efeito de -103\% na variação da PII. Assim, as transações correntes explicaram $78 \%$ da variação da PII no período.

Portanto, a variação do passivo externo líquido do período foi decorrente do efeito "despoupança" causado pelas rendas enviadas ao exterior e, não obstante a transferência de recursos reais ao exterior, ampliou-se o endividamento externo líquido em termos absolutos. Este aumento do valor da PII negativa esteve totalmente relacionado ao efeito circular entre a PII e as rendas líquidas enviadas, podendo-se concluir que a dinâmica de evolução dos estoques externos brasileiros nesse período foi determinada primordialmente por esse aspecto, com as outras contas apenas atenuando a tendência. Nota-se, destarte, que a política de transferir recursos reais ao exterior apenas amenizou o movimento mais geral de elevação do passivo externo líquido, conseguindo gerar um relativo equilíbrio no saldo das transações correntes no final do período.

Outra forma de visualizar isso é por meio do Gráfico 3, no qual se nota que a PII se tornou crescentemente negativa em praticamente todos os anos - exceção a 1988. O outro indicador apresentado, que serve como proxy da circularidade entre as rendas líquidas enviadas e a variação anual da PII, comporta-se de forma menos volátil e apresenta tendência de queda ao longo do período - provavelmente em virtude da queda da rentabilidade dos passivos, por conta da redução dos juros internacionais. Além disso, também fica evidente que a mencionada circularidade é fundamental para explicar a dinâmica de evolução da PII - os anos que tiveram uma menor taxa de variação de aumento da PII (1984, 1985, 1988 e 1989) se caracterizaram pelos expressivos superávits comerciais (Tabela 6), que apenas amenizaram a tendência causada pela circularidade. 
Gráfico 3- Variação anual da PII (\%) e proxy da circularidade entre as rendas líquidas enviadas e a variação anual da PII (\%), 1981-1990

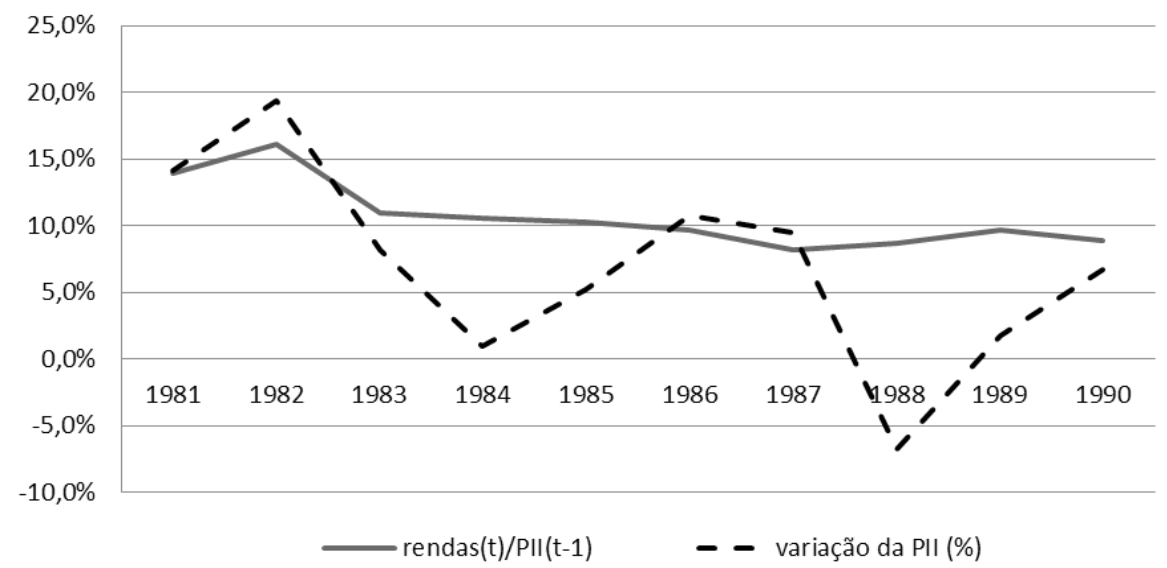

Fonte: Elaboração própria.

Nota: proxy da circularidade entre rendas e variação anual da PII = rendas líquidas enviadas ao longo do ano t/estoque da PII ao final do ano t-1; PII = Posição Internacional de Investimentos.

Dessa maneira, conclui-se que a circularidade entre a PII e as rendas líquidas enviadas é o principal fator para explicar a vulnerabilidade externa potencial da economia brasileira. Mesmo em um período de manifestação dessa vulnerabilidade, em que enormes esforços foram realizados e com sérias consequências, nota-se que o passivo externo líquido continuou se expandindo, gerando uma ampliação da dependência dos financiamentos externos, fatores que ajudam a explicar a debilidade de economia doméstica na década seguinte e representando o germe de novas crises.

\section{Considerações Finais}

Um dos elos mais importantes da interação entre fluxos e estoques externos brasileiros está na sua circularidade, ou seja, a Posição Internacional de Investimentos (PII) negativa causa uma saída de rendas e este fluxo está diretamente relacionado com o aumento do passivo externo. Diante desta dinâmica de evolução dos estoques externos, a vulnerabilidade externa caracteriza-se pela dependência em relação aos financiamentos estrangeiros, fazendo com que os momentos de escassez de liquidez no plano internacional resultem em medidas restritivas na economia doméstica. Assim, um dos objetivos deste trabalho foi demonstrar como essa circularidade evoluiu e afetou a vulnerabilidade externa do país no período 
1980-1990, um dos momentos da história econômica brasileira no qual essa vulnerabilidade se manifestou de forma mais explícita.

Vale observar que no Brasil, em termos históricos, a economia é estruturalmente deficitária em rendas, praticamente desde a constituição do país como nação independente. Esses recursos que devem ser enviados ao exterior originam uma permanente necessidade de geração de divisas geralmente não satisfeita pelo "lado real" da economia (superávits da balança comercial e de serviços), fazendo com que o país fique dependente do financiamento estrangeiro para fechar suas contas externas. Essa condição constitui-se, portanto, como uma das causas da vulnerabilidade externa brasileira, sobretudo em momentos de reversão do contexto internacional de liquidez.

A situação de escassez de liquidez no âmbito internacional afetou a economia brasileira entre 1980-1990 de forma aguda, portanto, pode-se considerar que o período analisado se caracterizou como de manifestação inequívoca da vulnerabilidade externa decorrente da PII e do fluxo de rendas. Diante disso, o país parece ter utilizado todos os instrumentos disponíveis em prol do objetivo de transferir recursos reais ao exterior para servir os encargos dos estoques externos. Os saldos positivos gerados pelas exportações serviram apenas para amenizar a circularidade entre PII e rendas enviadas ao exterior, atenuando o aumento do passivo externo líquido, mas gerando um baixo dinamismo econômico e o aumento das pressões inflacionárias.

De acordo com os dados apresentados sobre os fatores que levaram à variação da PII no período, chega-se à conclusão de que a redução da absorção em relação à produção doméstica serviu apenas para amenizar o aumento do endividamento externo. Isso porque ocorreu uma elevação do passivo externo líquido de US $\$ 68$ bilhões no período, causado pelas rendas líquidas enviadas ao exterior (esse fator representou $181 \%$ da variação da PII), corroborando a hipótese levantada nesse trabalho de que o efeito "despoupança" (gerado pelas rendas líquidas enviadas ao exterior) deve ser melhor qualificado nas análises referentes aos desequilíbrios observados nos balanços de pagamentos dos países e, portanto, sobre a vulnerabilidade externa sob a ótica financeira.

Dessa maneira, pode-se concluir sobre a incapacidade de a economia brasileira gerar fluxos para resolver uma crise de estoques. O artigo mostra que o expressivo aumento do passivo externo líquido teve no efeito circularidade entre as rendas líquidas enviadas e a PII o seu principal determinante. Foram apresentados elementos suficientes, por meio de diversos indicadores de endividamento externo, para se concluir que a vulnerabilidade externa da economia brasileira se deteriorou no começo da década e que o enorme esforço de transferir recursos reais ao exterior para satisfazer os credores apenas amenizou essa situação na segunda 
metade da década de 1980, gerando um período de baixo dinamismo econômico e efetivamente configurando a década perdida.

\section{Referências}

ABREU, M. P. (Org.). A ordem do progresso: dois séculos de política econômica no Brasil. 2. ed. Rio de Janeiro: Elsevier, 2014.

. Os funding loans brasileiros: 1898-1931. Pesquisa e Planejamento Econômico, v. 32, n. 3, p. 515-540, dez. 2002.

ARAUJO, M. S. Estatísticas do setor externo. In: FEIJÓ, C.A. et al. Para entender a conjuntura econômica. Barueri: Manoele, 2008.

Estimativa dos Ganhos de Detenção Nominais de ativos financeiros: uma aplicação

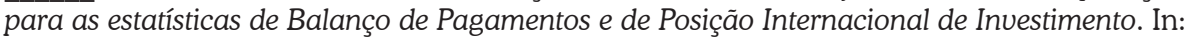
IBGE. II Encontro Nacional de Produtores e Usuários de Informações Sociais, Econômicas e Territoriais, 2006.

BANCO CENTRAL DO BRASIL. SGS - Sistema Gerenciador de Séries Temporais. 2017. Disponível em: <http:/www.bcb.gov.br/htms/infecon/Seriehist_bpm5.asp>. Acesso em: 05 jan. 2017.

BATISTA JÚNIOR, P. N. Da crise internacional à moratória brasileira. Rio de Janeiro: Paz e Terra, 1988.

. Formação de capital e transferência de recursos ao exterior. Revista de Economia Política, v. 7, n. 1, p. 10-28, jan./mar. 1987.

BELLUZZO, L. G. M. As transformações da economia capitalista no pós-guerra e a origem dos desequilíbrios globais. In: CARNEIRO, R. (Org.). A supremacia dos mercados e a política econômica do governo Lula. São Paulo: Unesp, 2006.

. O dinheiro e as metamorfoses da riqueza. In: TAVARES, M.C; FIORI, J. L. Poder e dinheiro. Uma economia política da globalização. Rio de Janeiro: Vozes, 1997.

BELLUZZO, L. G. M.; ALMEIDA, J. S. Depois da queda: a economia brasileira da crise da dívida aos impasses do real. Rio de Janeiro: Civilização Brasileira, 2002.

BIANCARELLI, A. M. A abertura financeira no Brasil: um balanço crítico. In: CARNEIRO, R.; MARCOLINO, L. C. Sistema financeiro e desenvolvimento no Brasil: do Plano Real à crise financeira. São Paulo: Publisher Brasil; Editora Gráfica Atitude, 2010. p. 55-88.

. Integração, ciclos e finanças domésticas: o Brasil na globalização financeira. 2007. 250 f. Tese (Doutorado em Economia) - Instituto de Economia da Unicamp, Campinas, 2007.

CARNEIRO, D. D.; MODIANO, E. Ajuste externo e desequilíbrio interno: 1980-1984. In: ABREU, M. (Org.). A ordem do progresso: dois séculos de política econômica no Brasil. Rio de Janeiro: Elsevier, 2014. 
CARNEIRO, R. Desenvolvimento em crise: a economia brasileira no último quarto do século XX. São Paulo: Unesp: IE-Unicamp, 2002.

. Globalização e inconversibilidade monetária. Revista de Economia Política, v. 28, n. 4 (112), p. 539-556, out./dez. 2008.

CASTRO, A. B.; SOUZA, F. E. P. A economia brasileira em marcha forçada. Rio de Janeiro: Paz e Terra, 1985.

CHINN, M.; PRASAD, E. S. Medium-term determinants of current accounts in industrial and developing countries: An empirical exploration. Journal of International Economics, v. 59, n. 1, p. 47-76, 2003.

CRUZ, P. D. Endividamento externo e transferência de recursos reais ao exterior: Os setores público e privado na crise dos anos oitenta. Nova Economia, v. 4, n. 1, ago. 1995.

. Notas sobre o financiamento de longo prazo na economia brasileira do após-guerra. $\overline{R e v i s t a}$ Economia e Sociedade, v. 3, n. 3, p. 66-81, dez. 1994.

CYSNE, R. P. Passivo Externo Líquido Versus Dívida Externa Líquida. Revista Conjuntura Econômica, v. 62, n. 6, p. 26-28, jun. 2008. Disponível em: <www.fgv.br/professor/rubens/ homepage/artigos_e_reportagens_de_pol_econ/artigos_publicados/2008/passivo\%20 externo.pdf > . Acesso em: 16 nov. 2009.

DE CONTI, B. M. Políticas cambial e monetária: os dilemas enfrentados por países emissores de moedas periféricas. 2011. 212 f. Tese (Doutorado em Economia) - Instituto de Economia da Unicamp, CEPN/Universidade Paris 13, Campinas, 2011.

DUMÉNIL, G.; LÉVY, D. O neoliberalismo sob a hegemonia norte americana. In: CHESNAIS, F. (Org.). A finança mundializada. São Paulo: Boitempo Editorial, 2005.

GARCIA, M. G. P. Vulnerabilidade externa e deficiência de poupança interna. Valor Econômico, 28 dez. 2001. Disponível em: <http://www.economia.puc-rio.br/mgarcia/ Artigos/Artigos\%20Valor/vulnerabilidade.PDF > Acesso em: 05 dez. 2016.

GONÇALVES, R. Capítulo V: Poder e Vulnerabilidade Externa. In: GONÇALVES, R. et al. A nova economia internacional: uma perspectiva brasileira. São Paulo: Campus, 1998.

IBGE. Estatísticas históricas do Brasil: séries econômicas, demográficas e sociais de 1550 a 1988. 2. ed. ver. e atual. do v. 3 de Séries Estatísticas Retrospectivas. Rio de Janeiro: IBGE, 1990.

INTERNATIONAL MONETARY FUND. World Economic Outlook. Washington, DC: IMF, Sept. 2005.

IPEADATA. Balança Comercial (FOB) - saldo: anual de 1899 até 1939. Disponível em: <http://www.ipeadata.gov.br/Default.aspx> . Acesso em: 15 jun. 2017.

LARA RESENDE, A. A ruptura no mercado internacional de crédito. In: ARIDA, P. Dívida externa, recessão e ajuste estrutural: o Brasil diante da crise. Rio de Janeiro: Paz e Terra, 1983. p. 41-54. 
MIRANDA, J. C. Dinâmica financeira e política macroeconômica. In: TAVARES, M. C.; FIORI, J. L (Org.). Poder e dinheiro: uma economia política da globalização. Petrópolis: Vozes, 1997, p. 15-24.

NOIJE, P. V. A vulnerabilidade externa decorrente da posição internacional de investimento $e$ do fluxo de rendas: uma análise da economia brasileira no período de 1953-1963. 2010. 199 f. Dissertação (Mestrado em Economia) - Pontifícia Universidade Católica de São Paulo, São Paulo, 2010.

PRATES, D. M. Crises financeiras dos países "emergentes": uma interpretação heterodoxa, 2002, 206 f. Tese (Doutoramento em Economia) - Instituto de Economia da UNICAMP, Campinas, 2002.

SILVA, A. C. M.; SANTOS, C. H. Além do curto prazo? Explorando os nexos entre a teoria pós-keynesiana e a macrodinâmica de fluxos e estoques. Campinas: IE/UNICAMP, abr. 2008. (Texto para Discussão IE/UNICAMP, n. 141).

SIMONSEN, M. H.; CYSNE, R. P. Macroeconomia. 3. ed. Rio de Janeiro: Atlas, 2007.

TAVARES, M. C. Da substituição de importações ao capitalismo financeiro. Rio de Janeiro: Zahar, 1972.

TAVARES, M. C.; BELLUZZO, L. G. M. A mundialização do capital e o poder americano. In: FIORI, J. L. O poder americano. Rio de Janeiro: Vozes, 2005.

UNCTAD. UNCTADSTAD Disponível em: <http://unctadstat.unctad.org/wds/ReportFolders/ reportFolders.aspx?IF_ActivePath $=$ P,15912EsCS_ChosenLang $=$ en $>$. Washington, DC: UNCTAD, 2017. Dispoñivel em: <http://www.unctad.org> Acesso em: 05 jan. 2017.

Recebido em: 24/01/2017. Aceito em: 26/06/2017. 